\title{
Legal Countermeasures for Financial Development in National Autonomous Areas
}

\author{
Liangsha $\mathrm{Gu}^{1, \mathrm{a}}$ \\ ${ }^{1}$ Oxbridge College, Kunming University of Science and Technology, Kunming, Yunnan Province, \\ China \\ a16451415@qq.com
}

Keywords: National Autonomous Areas; Financial Development; Legal Countermeasures.

\begin{abstract}
Related laws play important roles in protecting and promoting the financial development in national autonomous areas. At present, the government has issued a series of laws to legally promote and protect the financial development in national autonomous areas. But these supports are not strong enough to meet the demands of financial development in these areas. Based on the analysis of the deficiencies in existing laws, this paper puts forward to solutions and legal countermeasures for financial development in national autonomous areas, including measures to improve provisions in existing laws, and the construction of financial risk prevention legal system in national autonomous areas.
\end{abstract}

\section{Introduction}

Since China implemented the reform and opening up policy, the economy in national autonomous regions has developed a lot. But generally speaking, the economic levels in these areas still lagged behind other areas. The backward financial industry in these areas is an important reason for slow economic development. The performances of backward financial industry in national autonomous areas go as follows. First, the financial industry in these areas has developed to some extent, but the deposit amount is still small. After our country adopted the policy of reform and opening up, financial industry in national autonomous regions has developed from scratch with a rapid speed. But due to the low levels of overall development and the low degrees of economic monetization, the whole volumes of deposits and loans in national autonomous regions are relatively small. For example in Sichuan, the balance of deposits and loans in ethnic minority autonomous regions only accounts $5 \%$ of the total deposits and loans balance in the province. The loan growth rates of financial institutions are also far less than the gross domestic product growth rate. Second, there are only small number and single category of financial institutions in these areas. People there are lack of diversified financial instruments. The levels of economy development in national autonomous regions are still lagging behind other areas. As a result, demands for financial services there are also less than developed areas. In consideration of reducing costs and making profits, no financial institutions are willing to establish regional branches in national autonomous regions, except for state-owned commercial banks, policy banks and state-owned non-banking financial institutions. Other national or regional joint-stock banks do not want to step into these areas, let alone these foreign financial institutions. The single variety of financial institutions directly restricts the diversification of financial instruments. Thus, there are only limited kinds of financial services in national autonomy regions. Third, financial services there are inefficient and disorder. Financial institutions in national autonomous areas are lack of innovations; operations of capital in financial markets are inefficient; financial order disorder. On solving the financial development lag in national autonomous areas, researchers do not only need to make discussions on economy, legal countermeasures for financial development are also need to be discussed to provide legal protection for financial development in national autonomous regions. 


\section{Analysis on the Importance of Laws for Financial Development in National Autonomous Regions}

Laws can guarantee the right to financial development in national autonomous regions. In the initial stages of reform and opening-up, in order to speed up China's economic development, the government implemented the efficiency-oriented development strategy. It was a regional imbalance development strategy. Namely, the country vigorously supported the development of eastern areas, and expected that the development of central and western regions could be promoted by the development of eastern areas. Although this strategy played a great role in promoting the development of national economy, it also brought adverse consequences, include the imbalance in economic development between east areas and middle-western areas, especially the national autonomous regions. The development gap is still widening now. In order to ensure national equality and fair development, and to protect the poor and disadvantaged areas, it is necessary to provide inclined protection and priority support to the financial development in national autonomous areas. Related measures should be used to guarantee the fast development of financial industries in these regions, and to continuously reduce the gap on financial development between national autonomous areas and the eastern region. The right to financial development is a fundamental right in national autonomous areas. These areas are in weak positions in economic development, and they should enjoy the fair chance of financial development and the fair results in the future. The government has legally recognized and protected this right. The Constitution clearly stipulates the principle of ethnic equality and the common prosperity of all nationalities, which lay a solid foundation for the protection of financial development in national autonomous regions. The Law of National Ethnic Autonomy offers specific provisions on financial development in national autonomous regions. Some administrative regulations and local rules provide detailed implementation measures on financial development in national autonomous regions. [1]

Laws can prevent and control financial risks in national autonomous areas. Financial risk refers to the risks associated with financial affairs. In the process of financial operation, uncertain factors influence the financial markets and the subjects in financial markets. Thus, loss of financial capital may occurs, and the normal development of their own may be affected negatively. Financial risks in national autonomous areas fall into the following five categories. First, liquidity risks of financial institutions. In order to increase profits, some financial institutions in national autonomous areas are like to put large amount of money into long-term assets with high yield rate. But these assets have poor liquidity. Meanwhile, many economic subjects in these regions are engaging in agricultural production. During the planting season, farmers' loans increase greatly, and liquidity risks are likely to occur because financial institutions have put too much money into these long-term assets with low cashibility. Second, credit risks. Most borrowers in national autonomous areas are villagers, farmers and small, medium-sized enterprises. They do not have qualified collaterals. Meanwhile, financial institutions' credit evaluation methods are not good and advanced enough to define borrowers' credit levels. Thus, some borrowers who have got loans may not abide by the contract, and repay the principal and interest in time. Third, risks of financial personnel's quality. Financial institutions in the national autonomous areas are generally in small scales, and local people usually use their native language instead of mandarin to communicate. In order to solve the problem of communication, most employees in financial institutions are recruited locally. The majority of them do not have good education background and business quality, and they are usually lack of risk awareness. Fourth, management risks. Compared with economic subjects in developed areas, economic subjects in national autonomous regions are in weak positions. Their financial conditions are relatively poor due to the influences and restrictions of natural environment conditions and economic development situation. Therefore, financial institutions which provide services to them usually face difficulties and risks in business operation. Fifth, risks of government intervention. Financial industries in national autonomous regions cannot develop well without the promotion of local governments. But the boundary of government functions is difficult to define, and the pressures of financial development in national regions are very heavy. Compared with these developed areas with higher marketization 
degrees, financial systems in ethnic autonomous areas have higher risk of government intervention. [2] In the face of these financial risks, legal methods can be used to avoid, eliminate and reduce financial risks; they can also limit the scope of risks. Therefore, in order to ensure the stable and healthy development of financial industries in national autonomous regions, it is particularly important to use legal methods to prevent and control financial risks.

Laws can promote financial innovations in national autonomous regions. An important way to promote the financial development in national autonomous regions is to make financial innovations. These innovations should conform to the social and economic development situations of national autonomous regions. Financial innovations means changes the existing financial systems, and developing new financial instruments. Its purpose is to take potential profits which can not be taken by using existing financial systems and instruments. Laws play important roles in financial innovation. Almost all the activities in financial industries are carried out under the legal framework. If there's no law, there's no financial system. Both financial laws and other kinds of laws can promote financial innovations. For example, most enterprises in national autonomous regions are small and medium-sized enterprises. They usually do not have qualified collaterals. That leads to large financial institutions' financing difficulties. In order to solve this problem, financial innovations must be made. The Property Law issued in 2007 regulates that, properties which can be acquired in the future can be used to obtain guarantee. The law also creates new guarantee methods include floating mortgage, tiptop possessory pledge and receivables pledge. These regulations extremely promote the innovation in financial industry, and promotes the financial development in national autonomous regions. [3]

\section{The Support of Current Laws to Financial Development in National Autonomous Areas and Existing Problems}

The support of existing laws to financial development in national autonomous areas. In order to promote the financial development in national autonomous areas, important laws are deliberated and passed by the National People's Congress. These laws include Law of the People's Bank of China, Commercial Bank Law, Law of Negotiable Instrument, Law of Insurance, Securities Law and Guarantee Law. These laws combine the requirements of establishing socialist market economy and the needs of financial system reform together, and learn form the successful experiences of foreign countries. These laws help to create legal environment for the financial development in national autonomous regions. In addition, the Law of Regional National Autonomy, and the Provisions of the State Council on the Implementation of Law of Regional National Autonomy, also provides legal supports and protections for the financial development in national autonomous regions. In the Law of Regional National Autonomy, articles 35, 56, 57, 58, 60 and 63 make specific provisions on financial development in national autonomous areas. First, authorities in national autonomous areas can set up local commercial banks and urban, rural credit cooperative organizations according to the economic development levels and social demands of these areas. Second, on the basis of market need and the unified planning policy, the government can give priority to resource exploitation projects and infrastructure projects in national autonomous regions. For major infrastructure construction projects, the government can increase the investment proportions and the proportions of loans from policy banks. Third, the state should consider the economic situations and market demands of national autonomous regions, increase financial supports to these regions, and make full use of monetary markets and capital markets. In national autonomous areas, the fixed assets investment projects and enterprises which are in line with state industrial policies should be strongly supported by financial institutions. These supports ought to meet their reasonable financial needs on resource exploitation and diversified economy development. Encouraging commercial banks to increase credit input in national autonomous areas and actively support the reasonable capital requirements of local enterprises. Fourth, state organs at higher levels should help enterprises in national autonomous areas to realize technology innovations and industrial structure upgrading from the aspects of fiscal, finance and personnel. At the same time, according to ethnic trade policies and the needs of national autonomous areas, financial supports and assistance should be provided to national autonomous areas. Supports in investment, finance and tax should be made to 
improve infrastructure construction. In the Provisions of the State Council on the Implementation of Law of Regional National Autonomy, articles 11 and 12 provide legal supports to financial development in national autonomous areas. First, the state needs to increase financial support to national autonomous areas through helping them to broaden financing channels. We can encourage financial institutions to support major construction projects and rural projects in national autonomous areas from the perspective of credit investment. Under certain conditions, we can give priority to offering projects in national autonomous areas with foreign governments, grants and concessional loans arranged by state organs at higher levels. Second, give privilege on the tax, financial and fiscal policy to ethnic trade projects and enterprises dealing with special goods for ethnic minority and traditional crafts.

Current laws have shortcomings on promoting financial development in national autonomous areas. Though these laws have promoted the financial development in national autonomous areas greatly, their support cannot meet the demands of financial development in these regions. Shortcomings and deficiencies still exist, and displays mainly in following aspects.

The Law of Regional National Autonomy provides supports for financial development in national autonomous regions. However, many other laws do not provide relative supports or preferences to these regions. For example in Law of Regional National Autonomy, article 57 stipulates that the government should use monetary markets and capital markets, and increase financial supports to these regions. While in Law of the People's Bank of China, the Commercial Bank Law, and the Securities Law, there's a little regulations on supporting financial development in national autonomous regions. Hence, there's no legal basis on using the monetary markets and capital markets to support financial development in national autonomous regions. At the same time, in Law of Regional National Autonomy, article 57 stipulates that commercial banks are encouraged to increase credit input in national autonomous areas, and to actively support the local enterprises' reasonable capital requirements. But in the Commercial Bank Law, credit operations of commercial banks are strictly defined. National undifferentiated credit policies and management systems are used here. The General Provision of Loan also gives specific provisions on the conditions and procedures for loan. These laws and regulations do not make preferential policies for national autonomous areas, and leads to the consequence that a lot of ethnic trades and ethnic articles production enterprises can not meet the requirements for loan. In addition, in accordance with the Commercial Bank Law, commercial banks are business entities which take making profits as their operation purpose. Commercial banks need to focus on the safety, profitability and liquidity of assets. So it is difficult for them to participate in the non-profit activities of supporting national autonomous areas. What's more, according to article 35 from the Law of Regional National Autonomy, national autonomous areas can set up commercial banks and urban, rural credit cooperative organizations in accordance with the law. But their registrations capitals should reach the unified national standards. This provision does not take the relatively weak economy status in national autonomous region into consideration. People there are short of funds. Therefore, new financial institutions can not be established in national autonomous areas as their registered capital can not meet the statutory requirement.

There are no good legal systems on financial risk prevention in national autonomous areas. The financial industry is a industry with very high levels of risk. Guarding against financial risks is the prerequisite of financial security and the efficient, healthy development of financial industry in ethnic regions. In the process of preventing financial risks in ethnic autonomous areas, the establishment and improvement of legal systems on financial risk prevention is particularly important. These laws should conform to the actual conditions of national autonomous areas. At present, although the Law of the People's Bank of China, the Commercial Bank Law, the Securities Law and other laws have made regulations and provisions on construction of legal systems to prevent financial risks, the financial legal system on risk prevention do not conform to the situations of financial industries in national autonomous areas. These laws block the financial development in national autonomous regions. Under that situation, it is particularly urgent to establish and perfect legal system on financial risk prevention in national autonomy regions. 


\section{Legal Countermeasures to Protect Financial Development in National Autonomous Areas}

Strengthening legislation and perfecting existing regulations on financial development in national autonomous regions. To accelerate the financial development in national autonomous regions, the working force on legislation must be increased. First, modifying the Law of the People's Bank of China, changing the present unit central bank system, and implementing central bank system which combines centralization and decentralization. Due to the differences on economic development status and financial environment between national autonomous regions and developed areas, when making financial policies, the central bank must take the particularity of national autonomous areas into account. But the central bank does not know enough about the financial statuses and development trends of national autonomous areas. What's more, when the central bank makes financial policies, the situation of the whole country must be considered. Therefore, these policies may not suitable to actual circumstances in national autonomous areas. Therefore, under the premise of head office's control on country's financial situations and monitoring on is branches; regional branches in national autonomous regions can have more decision-making powers to make regional financial policies. Branches in national autonomous regions should proactively pay attention to the financial development situation in the local area, formulate and implement financial policies which are suitable to actual situations in national autonomous areas, and promote the financial development of the local area. Second, relevant provisions in the Commercial Bank Law must be revised. Obligations and responsibilities of commercial banks in prompting financial development in national autonomous areas should be defined. On the basis of ensuring fund security, the authority needs to make the minimum standards for the rate between credit loans which are provided to meet the capital needs in minority nationality regions and the profits which are obtained through deposits in this region. Commercial banks must provide credit funds to national autonomous areas no less than this rate, in order to ensure the funds in the hands of the localities can better service local development. Third, to deepen provisions which are good to financial development in national autonomous regions in current laws and regulations. For example, in order to cooperate with the regulations in the Law of Regional National Autonomy which encourages commercial banks to increase credit input in the national autonomous areas, the rate of deposit and loan reserve in commercial banks in ethnic autonomous regions can be decreased appropriately. At the same time, in order to increase the amount of money which are used in commercial banks' credit input, the power to adjust interest rates can be given to commercial banks in national autonomous regions to appropriately raise deposit rates, in order to turn a large amount of idle capital in society into the development funds for national autonomous regions. For these important state-support infrastructure projects in national autonomous regions and major projects which need large amount of money, the loan rates can be appropriately reduced. Meanwhile, on the basis of government's financial support, syndicated loan can be used to support these projects. [4]

Constructing legal system on financial risk prevention in national autonomous areas. Supervision organizations in the central bank should strengthen their regulations on the financial operation status in national autonomous regions. These regulations from central bank should transform from compliance regulation to prudential supervision which combines compliance regulation and risk prevention. According to the requirements of prudential supervision, the types and causes of financial risks in national autonomous areas should be analyzed carefully and comprehensively. Then, on the basis of these analyses, a complete and accurate financial risk monitoring index system should be established. This system needs to include scientific risk assessment indicators, standardized financial statements and statistic analysis. Meanwhile, risk monitoring centers and warning centers are also need to set up in national autonomous areas. By using advanced technologies such as the computer network, the collection, classification, analysis and judgment of supervision information can be improved. In this way, financial institutions can timely find potential risks in national autonomous areas, and take concrete, effective risk prevention measures to resolve these potential risks.

To improve the risk control ability of financial institutions in national autonomous regions. One, we can cultivate talent financial teams in national autonomous areas. The paper discusses the 
categories of financial risks above, and points out that one of these risks is the quality of financial personnel. Usually, staffs in financial institutions in national autonomous areas do not have high education levels and professional qualities, and are lack of risk awareness. In order to improve the risk control ability of financial institutions in national autonomous areas, it is necessary to cultivate talent teams. Employees' professional qualities and risk prevention capacities should be strengthened, as well as the awareness of risk control. Two, we can promote the internal controlling construction in financial institutions in national autonomous areas, and to establish a reasonable internal controlling system. Making strict post division; clearly defining job responsibilities; making each department relative independence and can cooperate with each other. At the same time, we can promote the approval procedure of credit authorization, strengthening supervision and restriction to powers, preventing the illegal use of authority and power out of control. Constantly revising and improving internal control rules and regulations, strengthening the systematicness and operability of internal control system. Three, further perfecting the legal-person governance structure of financial institutions in national autonomous areas. On the basis of ownership and management separation, giving full play to the board of directors' and risk control committees' supervision on the management layer. We could establish effective interest balance system and interaction mechanism between the owners, operators, regulators and other stakeholders.

To create a good credit environment in national autonomous areas. One category of financial risks is the credit risk. In order to prevent financial risks in national autonomous areas, the credits of local, industry, enterprises and capital market must be used to improve the social credit order, to make the market subjects keep honest and integrity, and to promote the sustainable and healthy development of the financial industry in national autonomous regions. [5]

\section{References}

[1] Z.H. Tan, S.S. Yin, Analysis on financial development in national regions and the construction of legal safeguard mechanism, J. Journal of Beifang University of Nationalities, philosophy and social sciences ed. 2 (2012) 16-21.

[2] Y. Zhao, Researches on financial risk prevention and control mechanism in rural areas in ethnic minority areas, Minzu University of China. 2013, 28 - 30

[3] D.B. Liu, Researches on the evolution of relationship between legal system and financial innovation, J. Journal of law. 5 (2013) 106-108.

[4] Z.W. Chen, Financial development in ethnic minority areas in the new period: constraining and breakthrough, J. Guizhou Ethnic Studies. 5 (2013) 128-131.

[5] F.M. Peng, The perfection of financial law system on promoting the coordinated development of regional economy, Hunan university, 2011, 27- 28. 